\title{
PENGARUH PEMBERIAN BERBAGAI ZAT PENGATUR TUMBUH ALAMI TERHADAP PERTUMBUHAN STEK KOPI
}

\section{THE EFFECT OF VARIOUS NATURAL PLANT GROWTH REGULATOR ON GROWTH CUTTINGS OF COFFEE}

\author{
I Tustiyani1a \\ 1 Program Studi Agroteknologi, Fakultas Pertanian, Universitas Garut \\ Jl. Raya Samarang No. 52-A, Garut. \\ a Korespondensi: Isna Tustiyani, E-mail: isnatustiyani@gmail.com \\ (Diterima: 14-02-2017; Ditelaah: 14-02-2015; Disetujui: 06-04-2017)
}

\begin{abstract}
The Coffee is one of national excellent commodities. The Nurseries of coffee generally through the beans, but it can be grown through vegetative through by cuttings treated with growth regulators. The purpose of this research was to study the effect of various naturally plant growth regulators in coffee cuttings. The experiment was conducted at the Experimental Farm, Faculty of Agriculture, University of Garut in October-November, 2016 using Randomized Complete Block Design with treatment without giving plant growth regulator, growtone, onion extract, and coconut water. The result showed that the extract of onion can grow at $50 \%$ and the growtone treatments can grow $55 \%$ of the coffee cuttings.
\end{abstract}

Keywords: auxin, coconut water, coffee cuttings, onion extract.

\begin{abstract}
ABSTRAK
Kopi merupakan salah satu komoditas perkebunan unggulan nasional. Pembibitan kopi umumnya melalui biji, padahal kopi dapat dibudidayakan melalui cara vegetative yaitu stek asal diberi perlakuan at pengatur tumbuh. Tujuan penelitian ini adalah untuk mempelajari pengaruh pemberian berbagai zat pengatur tumbuh alami pada stek kopi. Percobaan dilaksanakan di Kebun Percobaan Fakultas Pertanian, Universitas Garut pada Oktober November 2016 menggunakan Rancangan Acak Kelompok (RAK) dengan perlakuan tanpa pemberian ZPT, growtone, ekstrak bawang merah, dan air kelapa. Hasil percobaan dapat disimpulkan bahwa pemberian ekstrak bawang merah dapat menumbuhkan sebesar $50 \%$ dan penggunaan growtone sebesar $55 \%$ stek kopi hidup.
\end{abstract}

Kata kunci: auksin, air kelapa, ekstrak bawang merah, stek kopi.

Tustiyani I. 2017. Pengaruh pemberian berbagai zat pengatur tumbuh alami terhadap pertumbuhan stek kopi. Jurnal Pertanian 8(1): 46-50.

\section{PENDAHULUAN}

Kopi merupakan salah satu komoditas perkebunan unggulan yang memiliki prospek penting bagi penambahan devisa negara. Produksi kopi nasional pada tahun 2013 sebesar 30.500 ton dan meningkat menjadi 31.100 ton pada tahun 2014 (BPS, 2017). Beberapa produsen kopi di Indonesia terletak di propinsi Aceh, Sumatra Utara, Lampung, Jawa Barat, dan lain-lain. Salah satu produsen kopi di propinsi Jawa Barat adalah Kabupaten Garut. Luas areal perkebunan kopi di Garut tahun 2013 adalah 3.796 ha dengan produksi mencapai 1.766 ton berasan kopi (Garut Dalam Angka 2015).

Beberapa tahapan teknik budidaya tanaman adalah pembibitan, penanaman, 
pemeliharaan, pemupukan, panen dan pasca panen. Tahapan pembibitan merupakan fase awal yang akan menentukan tinggi rendahnya produksi kopi. Pembibitan kopi selama ini umumnya dilakukan secara generative melalui biji dan jarang dilakukan secara vegetative. Upaya perbanyakan secara vegetatif dapat dilakukan dengan beberapa cara yaitu stek, cangkok, dan okulasi. Pembibitan secara vegetative, contohnya stek, jarang dilakukan karena kemampuan batang kopi yang sulit berakar. Padahal keuntungan perbanyakan melalui stek batang antara lain tidak lama untuk menunggu waktu panen, memiliki sifat genetik yang sama dengan induk sehingga sifat unggul dari induk akan dapat dipertahankan (Yunanda et al. 2015).

Dalam perbanyakan tanaman melalui stek, organ tanaman yang umumnya digunakan antara lain cabang, pucuk, akar dan daun (Hartmann et al. 2002). Organ batang dan pucuk merupakan bahan tanaman yang relative mudah digunakan untuk perbanyakan melalui stek. Pemenuhan kebutuhan bibit dalam jumlah yang besar dan cepat dapat dilakukan dengan pembibitan melalui cara stek, namun dalam proses pembibitannya diperlukan zpt yang dapat merangsang pembentukan akar. Pembentukan akar yang merupakan salah satu proses fisiologis tanaman dapat dipengaruhi oleh adanya zpt yang umumnya mengandung senyawa organik bukan hara (Widyastuti dan Tjokrokusumo 2006).

Zat pengatur tanaman dapat diproduksi oleh tanaman sendiri dan seringkali dalam jumlah sedikit sehingga diperlukan penambahan sumber dari luar. Pemberian ZPT pada saat penyetekan akan membuat kualitas bibit akan meningkat dan jumlah bibit dibawah standar normal akan menurun. (Salisburi dan Ross 1995). Berdasarkan sumbernya, ZPT dapat diperoleh baik secara alami maupun sintetik. Beberapa contoh ZPT adalah air kelapa, urin sapi, dan ekstraksi dari bagian tanaman (Zhao 2010). ZPT yang bersumber dari alam memiliki beberapa kelebihan antara lain lebih ramah lingkungan, mudah didapat, aman digunakan, dan lebih murah.

Tidak semua jenis tanaman dapat dibiakkan dengan stek,. Salah satu kendala tanaman tidak bisa dibiakkan secara stek adalah kemampuan tanaman untuk berakar. Beberapa hal yang membuat tanaman tidak dapat berakar setelah dilakukan penyetekan adalah kandungan lignin yang tinggi dan kehadiran cincin sklerenkim yang dapat menghalangi tempat munculnya akar adventif (Hartmann et al. 2002). Umur bahan stek, jenis tanaman, adanya tunas dan daun muda pada stek, persediaan bahan makanan, dan zat pengatur tumbuh adalah beberapa hal yang mempengaruhi penyetekan (Zong et al. 2008). Tujuan penelitian ini adalah untuk mengetahui pengaruh beberapa zat pengatur tumbuh terhadap pertumbuhan stek kopi.

\section{MATERI DAN METODE}

\section{Materi}

\section{Waktu dan Tempat}

Penelitian dilakukan kebun percobaan Fakultas Pertanian Universitas Garut pada Bulan Oktober sampai dengan November 2016. Pengambilan bahan tanaman dilakukan dari perkebunan kopi di Kecamatan Cikajang Kabupaten Garut. Tanaman kopi. Bahan yang digunakan dalam penelitian ini adalah tanaman kopi umur 1,5 tahun (bahan stek kopi), zat pengatur tumbuh (Growtone, air, bawang merah, air kelapa, pupuk kompos, tanah, plastik sungkup, polibag dan lain-lain. Sedangkan alat yang digunakan adalah nampan, cangkul, gunting stek, gelas ukur, pisau cutter, cangkul, ember, alat tulis dan lain-lain.

Bahan stek berupa pucuk kopi diambil dari cabang sekunder yang masih berbatang hijau dan diambil dari 5 ruas dibawah pucuk. Bagian pucuk tersebut diambil kemudian dipotong dengan panjang stek sekitar 8-12. Bagian pangkal dipotong miring dengan gunting stek sehingga memberikan permukaan yang banyak untuk bersentuhan 
dengan media stek. Setiap daun di bahan stek dipotong sehingga tinggal menyisakan setengah dari luasan daun. Hal ini berfungsi untuk mengurangi penguapan pada bahan stek pucuk ketika ditanam. Bahan stek yang telah dipotong dimasukkan dalam ember berisi air untuk menjaga kelembabannya.

\section{Metode}

\section{Penyiapan Zat Perangsang Akar Stek}

Bahan perangsang stek yang digunakan adalah Growtone, bawang merah, dan air kelapa. Growtone merupakan zat perangsang akar sintetik yang memiliki kandungan asam asetik naftalen 3\% dan naftalen asetik amid $0.75 \%$. Growtone ini diambil $500 \mathrm{mg}$ yang dilarutkan dalam air hingga berbentuk pasta untuk 10 stek kopi. Bawang merah sebanyak 200 gram yang sudah berakar diblender untuk diambil sarinya. Bahan stek dimasukkan dalam air sebelum ditanam. Setelah bahan stek dan larutan zpt tersedia sesuai dengan dosis perlakuan kemudian bahan stek dicelupkan ke dalam larutan tersebut dan ditanam di media tanam.

Penelitian ini dilakukan menggunakan rancangan acak kelompok (RAK) yang terdiri dari 4 perlakuan dan 2 ulangan sehingga didapat 8 satuan percobaan. Setiap satuan percobaan terdiri 5 tanaman. Adapun perlakuan yang diberikan adalah tanpa perlakuan zat perangsang akar (kontrol) (P0), growtone (P1), ekstrak bawang merah (P3) dan air kelapa (P4). Data dianalisis dengan sidik ragam menggunakan program statistik SAS, jika terlihat pengaruh yang nyata perlakuan pada sidik ragam, dilanjutkan dengan uji Duncan (DMRT) pada taraf 5\%. Parameter yang diamati adalah persentase stek tumbuh (\%).

\section{HASIL DAN PEMBAHASAN}

\section{Pertumbuhan Tunas Bibit Tanaman Kopi}

Hasil rata-rata persentase stek tumbuh pada perlakuan berbagai zat perangsang akar dapat dilihat pada Tabel 1 dan Gambar 1.
Tabel 1 memperlihatkan bahwa stek kopi yang diberi perlakuan berbagai zat perangsang akar tidak memiliki perbedaan yang nyata dalam hal persentase stek tumbuh. Hal ini diduga karena pada awal pertumbuhan stek batang tanaman kopi lebih memanfaatkan cadangan makanan yang tersedia pada bahan stek dan penyiraman yang dilakukan selama penelitian. Penyiraman ini membantu mempercepat proses metabolisme pada bahan stek sehingga stek dapat tumbuh dan berkembang. Stek kopi yang diberi perlakuan growtone, ekstrak bawang merah dan air kelapa memiliki persen pertumbuhan masing-masing sebesar $55 \%, 50 \%$ dan $0 \%$ (Tabel 1).

Tabel 1 Pengaruh berbagai zat perangsang akar dengan pertumbuhan stek kopi

\begin{tabular}{lr}
\hline \multicolumn{1}{c}{ Perlakuan } & Stek Tumbuh (\%) \\
\hline Kontrol & 0 \\
Growtone & 55 \\
Bawang merah & 50 \\
Air Kelapa & 0 \\
\hline
\end{tabular}

Keterangan: Angka rata-rata yang diikuti huruf yang sama pada kolom yang sama menunjukkan berbeda tidak nyata berdasarkan Uji Jarak Berganda Duncan pada taraf nyata 5\%.

Perlakuan pemberian zat pengatur tumbuh tidak memiliki pengaruh nyata terhadap persen pertumbuhan stek. Belum berpengaruhnya persen pertumbuhan stek kopi setelah diberi perlakuan berbagai zat pengatur tumbuh diduga bahan stek yang digunakan belum memiliki jaringan meristem yang kuat. Jaringan meristem yang kuat umumnya dicirikan dengan ukuran diameter yang besar. Penelitian Pandjaitan et al. (2014) menunjukkan bahwa ukuran diameter bugenvil $18 \mathrm{~mm}$ memberikan pengaruh terbaik daripada ukuran diameter yang lebih kecil. Hartmann et al. (2002) menujukkan bahwa semakin jauh dari pucuk, ukuran diameter batang akan semakin besar dan akan memberikan pengaruh langsung terhadap kesuksesan pembentukan akar dan tunas karena perbedaan dalam kandungan karbohidrat dan zat lainnya. Bahan stek yang digunakan dalam penelitian ini adalah stek yang diambil 
dari 15-20 cm dari pucuk dengan panjang stek mencapai $15 \mathrm{~cm}$.

Selain bahan stek, pemberian zat pengatur tumbuh juga menjadi hal yang mempengaruhi keberhasilan stek untuk tumbuh (Zong et al. 2008). Zat pengatur tumbuh yang mempengaruhi kemampuan stek untuk berakar dan bertunas adalah sitokinin dan auksin Pembentukan akar pada stek dapat didorong oleh adanya zat pengatur tumbuh auksin dengan cara mengalokasikan penyebaran fotosintat pada akar untuk meningkatkan pertumbuhan akar tersebut (Panjaitan et al. 2014). Auksin juga berperan dalam proses pertumbuhan dan diferensiasi sel sehingga meningkatkan pertumbuhan vegetative (Gardener et al. 1991).

Gambar 1 dan Tabel 1 menunjukkan bahwa meskipun tidak berbeda nyata secara statistic, namun persen pertumbuhan stek yang diberi perlakuan ekstrak bawang merah adalah $50 \%$ sedangkan perlakuan air kelapa hanya $0 \%$. Hal ini dimungkinkan karena ekstrak bawang merah memiliki kandungan auksin. Menurut Marfirasi (2014) bawang merah memiliki kandungan auksin dan giberelin sehingga dapat memacu pertumbuhan benih. Pada beberapa penelitian menunjukkan bahwa pemberian ekstrak bawang merah mampu meningkatkan pertumbuhan bibit lada panjang (Sistwanto 2004), mempercepat pertumbuhan akar pada anakan salak (Sudaryono dan Soleh 1994) dan meningkatkan keberhasilan cangkok sebesar $10 \%$ pada cangkokan anakan salak (Kasijadi et al. 1999). Keberhasilan stek hidup Pembentukan akar dipengaruhi oleh keseimbangan auksin dan sitokinin (Bey et al. 2006).

Perlakuan pemberian air kelapa pada stek kopi tidak membuat stek kopi menunjukkan tanda kehidupan. Hal ini dimungkinkan karena air kelapa yang digunakan adalah air kelapa muda. Kandungan pada air kelapa yang sudah tua mengandung auksin $0.07 \mathrm{mg} / \mathrm{L}$, sitokinin 5.8 $\mathrm{mg} / \mathrm{L}$, (Bey et al. 2006) sementara air kelapa muda memiliki kandungan lebih kecil daripada kelapa tua. Penggunaan air kelapa yang sudah tua sebenarnya dapat memacu pertumbuhan akar pada stek karena mengandung auksin. Penelitian Marpaung dan Hutabarat (2015) menunjukkan bahwa penggunaan air kelapa dapat memacu pertumbuhan bibit buah tin. Dalam penelitian ini penggunaan air kelapa muda pada stek kopi tidak menunjukkan adanya tanda kehidupan (Gambar 1).

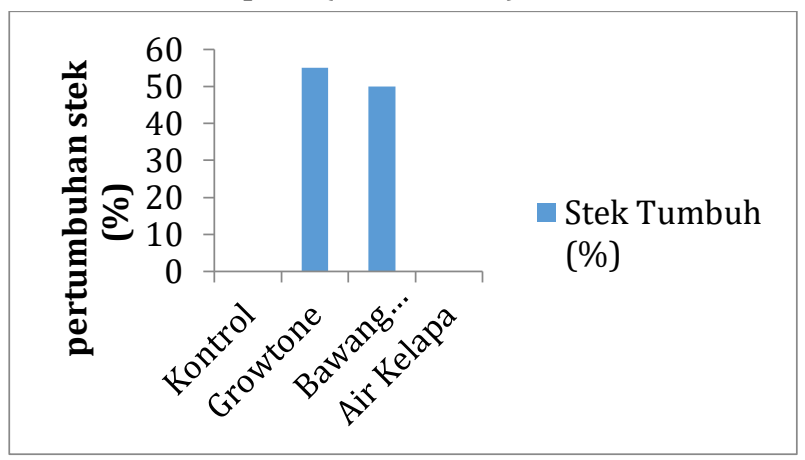

Gambar 1 Pengaruh berbagai zat perangsang akar dengan pertumbuhan stek kopi.

\section{KESIMPULAN DAN IMPLIKASI}

Berdasarkan hasil penelitian dapat diambil kesimpulan bahwa pemberian ekstrak bawang merah dapat menumbuhkan sebesar $50 \%$ dan penggunaan growtone sebesar $55 \%$ stek kopi hidup.

\section{DAFTAR PUSTAKA}

Bey, Y Syafii, dan W Sutrisna 2006. Pengaruh giberelin dan air kelapa terhadap perkecambahan anggrek bulan. J. Biogenesis 2 (2): 41-62

BPS. 2017. Badan Pusat Statistik. Diakses tanggal 14 Februari 2017 dari http// www.bps.go.id.

Garut Dalam Angka. 2015. Garut Dalam Angka. Badan Pusat Statistik Kabupaten Garut.

Hartmann HT, DE Kester, FT Davies, Jr, RL Geneve. 2002. Plant Propagation: Principles and Practices. Prentice Hall Inc. Engelwoods Clifs. New Jersey. 
Kasijadi F, Purbiati, T Mahfudi MC., Sudaryono, T., Soemarsono SR. 1999. Teknologi pembibitan salak secara cangkok. J. Hort 9 (1):1-7.

Marfirasi M. 2014. Pengaruh pemberian berbagai konsentrasi filtrate umbi bawang merah an rootone $\mathrm{F}$ terhadap pertumbuhan stek melati: Rato Ebu: lentera Bio: 3 (1): 73-76.

Marpaung AE dan RC Hutabarat. 2015. Respons jenis perangsang tumbuh berbahan alami dan asal stek batang terhadap pertumbuhan bibit tin (Ficus carica L). J. Hort 25 (1): 37-3

Panjaitan LRH., Ginting J., Haryati. 2014. Respon pertumbuhan berbagai ukuran diameter stek bugenvil (Baugainvilea spsctabilis Wild) terhadap pemberian zat pengatur tumbuh. Jurnal online agroekoteknologi 2(4): 1384-1390.
Salisburi FB dan CV Ross. 1995. Fisiologi Tumbuhan Jilid 3. ITB Press, Bandung.

Sudaryono dan Soleh. 1994. Induksi akar pada perbanyakan salak secara vegetative. Penel. Hort. 6 (2): 13-18.

Widyastutin dan D Tjokrokusumo. 2006. Peranan beberapa zat pengatur tumbuh (ZPT) tanaman pada kultur in vitro. Jurnal sains dan teknologi BPPT 3 (5): 55-63

Yunanda J, S Murniati, Yoseva. 2015. Pertumbuhan stek batang tanaman buah naga (hylocereus costaricensis) dengan pemberian beberapa konsentrasi urin sapi. JOM Faperta 2(1): 1-8.

Zhao Y. 2010. Auxin biosynthesis and its role in plant development. Ann. Rev. Plant Biol 61: 49-64.

Zong M. C., Yi Li and Zhen Z. 2008. Plant Growth Regulators Used in Propagation. CRC Press. Boca Raton, Florida. 